\title{
Pushing the Limits of Structurally-Diverse Light- Harvesting Ru(II) Metal-Organic Chromophores for Photodynamic Therapy
}

Roberto Padilla ${ }^{\mathrm{a}}$, William A. Maza ${ }^{\mathrm{a}}$, Anthony J. Dominijanni ${ }^{\mathrm{c}}$, Brenda S. J. Winkel ${ }^{\mathrm{b}}$, Amanda J. Morris ${ }^{\mathrm{a} *}$, and Karen J. Brewer ${ }^{\mathrm{a} \dagger}$

${ }^{a}$ Department of Chemistry, Virginia Tech, Blacksburg, VA 24061-0212 VA 24061-0212.

${ }^{\mathrm{b}}$ Department of Biological Sciences, Virginia Tech, Blacksburg, VA 24061-0406.

${ }^{\mathrm{c}}$ Department of Biomedical Engineering and Mechanics, Virginia Tech, Blacksburg, VA 24061-0442

* Corresponding author e-mail: ajmorris@vt.edu (Amanda Morris)

$\dagger$ Deceased October 24, 2014 


\section{ABSTRACT}

The synthesis of $\mathrm{Ru}(\mathrm{II})$ derivatives $\quad\left[(\text { AnthbpyMe)(bpy)Ru(dpp) }]^{2+}\right.$ (2) and $\left[(\text { AnthbpyMe })_{2} \mathrm{Ru}(\mathrm{dpp})\right]^{2+}(\mathbf{3})$, and the analysis of their excited state properties as well as their photocytotoxicity against glioma cells are reported. Complexes $\mathbf{2}$ and $\mathbf{3}$ absorb visible light with metal-to-ligand charge transfer (MLCT) transitions at $\lambda_{\max }=459 \mathrm{~nm}\left(16,000 \mathrm{M}^{-1} \mathrm{~cm}^{-1}\right)$ and $\lambda_{\max }=461 \mathrm{~nm}\left(21,000 \mathrm{M}^{-1} \mathrm{~cm}^{-1}\right)$, respectively. The complexes exhibit bichromatic properties with the ${ }^{3}$ MLCT emission centered at $\lambda_{\mathrm{em}}=661 \mathrm{~nm}$ and $\lambda_{\mathrm{em}}=663 \mathrm{~nm}$ for 2 and 3, respectively, while the anthracene motif(s) has emission from $450-560 \mathrm{~nm}$. The anthracene unit(s) quench the ${ }^{3}$ MLCT to give quantum yields (lifetime, $\tau$ ) of $\Phi_{\mathrm{em}}=0.0059(\tau=398 \mathrm{~ns})$ and $\Phi_{\mathrm{em}}=0.0011(\tau=414 \mathrm{~ns})$ for $\mathbf{2}$ and $\mathbf{3}$, respectively. The quenching rates were found to be $6.61 \times 10^{5} \mathrm{~s}^{-1}$ for 2 and $5.64 \times 10^{5} \mathrm{~s}^{-1}$ for 3 . Electrochemistry reveals an irreversible anthracene oxidation at $1.23-1.28 \mathrm{~V}$, while the $\mathrm{Ru}^{\mathrm{III} / \mathrm{II}}$ oxidation process occurs at a potential of $1.53-$ $1.55 \mathrm{~V}$. The complexes displayed a quasi-reversible reduction couple attributed to $\mathrm{dpp}^{0 /-1}$ at 0.98 V. Cytotoxicity of both complexes towards F98 glioma cells was moderate in the absence of light and substantially enhanced with visible light. 


\section{INTRODUCTION}

Ruthenium(II) tris(2,2'-bipyridine), $\left[\mathrm{Ru}(\mathrm{bpy})_{3}\right]^{2+} \quad($ bpy $=2,2$ '-bipyridine), and its derivatives have been extensively studied due to their rich ground and excited state properties. ${ }^{1-5}$ These photoactive molecules can be appended with rigid, highly conjugated, and planar organic chromophores through an insulating spacer to tune the photo-chemical and physical properties. ${ }^{6-14}$ These metal-organic $\mathrm{Ru}(\mathrm{II})$ complexes are known to modify vital biological macromolecules, such as DNA, through oxygen-mediated processes and show promising anticancer activity in vitro. ${ }^{15-21}$ However, the oxygen-dependence of these Ru(II) PDT agents limit their effectiveness against aggressive, highly-invasive, and neurologicallydestructive brain cancers (i.e. malignant gliomas) due to the hypoxic environments that commonly characterize these tumors. ${ }^{22-24}$ Thus, there is an urgent need for new molecular architectures of metal-organic $\mathrm{Ru}$ (II) PDT agents offering versatile photomodification pathways of vital cellular components (DNA, RNA, and proteins), independent of reactive oxygen species, to treat MGs and other intractable cancers.

Ruthenium PDT agents of the form $\left[(\mathrm{TL})_{2} \mathrm{Ru}(\mathrm{BL})\right]^{2+}\left(\mathrm{TL}=2,2^{\prime}\right.$-bipyridine (bpy), 1,10phenanthroline (phen), 4,7-diphenyl-1,10-phenanthroline $\left(\mathrm{Ph}_{2}\right.$ phen), and $\mathrm{BL}=2,3$-bis(2pyridyl)pyrazine (dpp)) are known to photooxidize DNA by ${ }^{1} \mathrm{O}_{2}$ generated through excited state energy transfer between the $\left[(\mathrm{TL})_{2} \mathrm{Ru}(\mathrm{BL})\right]^{2+}$ triplet metal-to-ligand, ${ }^{3} \mathrm{MLCT}$, excited state and molecular oxygen. ${ }^{25}$ Covalent coupling of known oxygen-independent DNA oxidizing agents through insulating amide bonds may offer an attractive approach for generating novel metal-organic $\mathrm{Ru}(\mathrm{II})$ chromophores to treat $\mathrm{MG}$ brain cancer through visible light activation. ${ }^{26-29} \mathrm{Ru}(\mathrm{II})$ chromophores containing dpp ligands possess the unique added advantage of being able to chelate biologically-relevant cations (i.e. $\mathrm{Na}^{+}, \mathrm{K}^{+}, \mathrm{Ca}^{2+}$, etc.), leading to disruption of cell homeostasis. ${ }^{30} \mathrm{Ru}$ (II) complexes that incorporate a $\pi$-expansive organic unit, such as anthracene, through diverse organic linkers demonstrate that photophysical properties and photodynamic potency can be influenced by controlling excited state dynamics. ${ }^{31,14}$ The $[\mathrm{Ru}]$-anthracene hybrid arrangement provides multiple pathways, singlet-singlet, triplet-triplet, and/or singlet-triplet, for deactivation of excited states through energy or electron transfer, which can increase the photoreactivity with biological molecules. Therefore, the proposed molecular architecture of the form anthracene-Ru(II)-dpp is a type of metal-organic $\mathrm{Ru}(\mathrm{II})$ complex that can offer multifunctional reactivity to enhance photodynamic potency against aggressive and invasive brain cancers.

Reported herein are two metal-organic $\mathrm{Ru}(\mathrm{II})$ complexes based on anthracene tethered via bpyMe (AnthbpyMe = 4-[N-(2-anthryl)carbamoyl]-4'-methyl-2,2'-bipyridine) to $\left[(\mathrm{bpy})_{2} \mathrm{Ru}(\mathrm{dpp})\right]^{2+}(\mathbf{1})$. The metal complexes, $\left[(\text { AnthbpyMe)(bpy)Ru(dpp) }]^{2+}\right.$ (2) and $\left[(\text { AnthbpyMe })_{2} \mathrm{Ru}(\mathrm{dpp})\right]^{2+}(\mathbf{3})$, were synthesized and their ground and excited states characterized (Figure 1). The complexes were also tested for photocytotoxicity against F98 rat glioma cells. The results of these studies indicate that these $\mathrm{Ru}(\mathrm{II})$-anthranyl complexes have promise for the development of multifunctional PDT agents. 


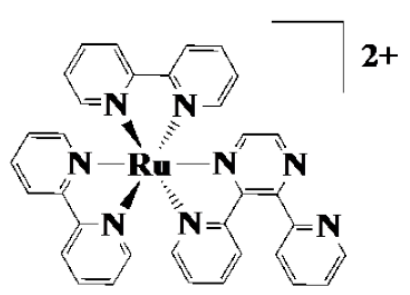

1

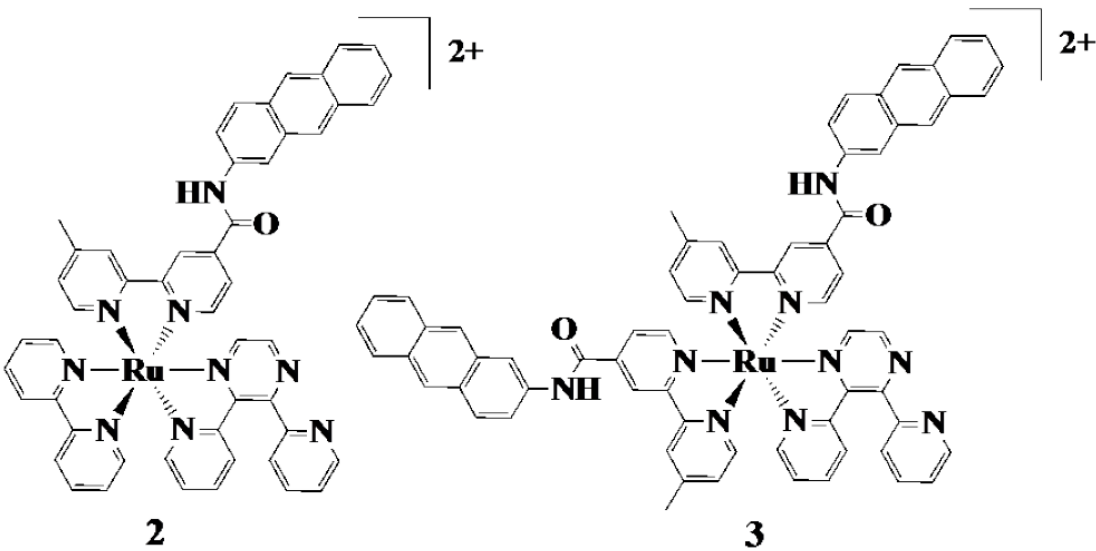

Figure 1. Chemical structures of $[(\text { bpy }) R u(d p p)]^{2+}(\mathbf{1}),[(\text { AnthbpyMe })(b p y) R u(d p p)]^{2+}$ (2), and $\left[(\text { AnthbpyMe })_{2} \mathrm{Ru}(\mathrm{dpp})\right]^{2+}(\mathbf{3})$, where bpy $=2,2^{\prime}$-bipyridine, dpp $=2,3$-bis $(2-$ pyridyl)pyrazine, and AnthbpyMe $=4$-[N-(2-anthryl)carbamoyl]-4'-methyl-2,2'-bipyridine.

\section{MATERIALS AND METHODS}

Materials: All solvents/chemicals were used as received unless otherwise noted and reactions were carried out under $\mathrm{Ar}_{(\mathrm{g})}$. $\mathrm{RuCl}_{3} \bullet 3 \mathrm{H}_{2} \mathrm{O}$ was purchased from Alfa Aesar. The ligands 2,2'bipyridine (bpy), 2-aminoanthracene, and 2,3-bis(2-pyridyl)pyrazine (dpp) were obtained from Aldrich, while the compounds $\left[(\mathrm{bpy})_{2} \mathrm{Ru}(\mathrm{dpp})\right]\left(\mathrm{PF}_{6}\right)_{2}$ 4-[N-(2-anthryl)carbamoyl]-4'methyl-2,2'-bipyridine (AnthbpyMe), and [(AnthbpyMe) $\left.\mathrm{Ru}(\mathrm{bpy})_{2}\right]\left(\mathrm{PF}_{6}\right)_{2}$ were prepared as described previously. ${ }^{8,32,33}$ Spectral grade acetonitrile was obtained from Burdick and Jackson. Tetrabutylammonium hexafluorophosphate $\left(\mathrm{Bu}_{4} \mathrm{NPF}_{6}\right)$ was purchased from Fluka. Sephadex LH-20 was purchased from GE Healthcare Biosciences Corporation. Alumina ( $80-200$ mesh) and silica $(230-400$ mesh) were purchased from Fisher Scientific.

Synthesis of [(AnthbpyMe)(bpy)RuCl $\left.\mathbf{l}_{2}\right]_{(\mathrm{s})}$ : To a solution of DMF: $\mathrm{H}_{2} \mathrm{O}(70 \mathrm{ml}, 6: 1)$ with 0.5 $\mathrm{g}$ of $\mathrm{LiCl}$, was added $0.090 \mathrm{~g}$ (2 equiv.) of bpy and $0.150 \mathrm{~g}$ (1 equiv.) of previously synthesized $\left.\left[\left(\eta^{6}-\mathrm{C}_{6} \mathrm{H}_{6}\right)_{2} \mathrm{RuCl}_{2} \mathrm{Ru}\left(\eta^{6}-\mathrm{C}_{6} \mathrm{H}_{6}\right)_{2}\right]\right]^{34,35} \mathrm{The}$ solution was then heated at $80^{\circ} \mathrm{C}$ under $\operatorname{Ar}_{(\mathrm{g})}$ and after $6 \mathrm{~h} 0.230 \mathrm{~g}$ of AnthbpyMe was added and the heating was continued at $110^{\circ} \mathrm{C}$ for an additional $6 \mathrm{~h}$. The solution was then cooled to room temperature and then the crude product was precipitated from $100 \mathrm{ml}$ of ether. The precipitate was collected by vacuum filtration and washed with $50 \mathrm{ml}$ of $\mathrm{H}_{2} \mathrm{O}$ and acetone, followed by drying in an oven overnight. The crude product was dissolved in a minimal amount of $\mathrm{CHCl}_{3}(1 \% \mathrm{MeOH})$ and then purified using two sequential chromatography columns. The sample was first loaded onto a 6-inch silica column, which was flushed with $100 \%$ ethyl acetate to elute organic impurities. The crude purple product band was then eluted using a $\mathrm{CH}_{2} \mathrm{Cl}_{2}(\approx 1 \% \mathrm{MeOH})$ as the mobile phase. The volume was reduced and the sample then loaded onto a 24 inch LH-20 column with $\mathrm{CHCl}_{3}$ as the mobile phase. The purple band was collected to give $0.200 \mathrm{~g}$ of the desired product in $47 \%$ yield. The compound was characterized by HPLC-MS and absorption spectroscopy (Figures S1 and S2). 
Synthesis of [(AnthbpyMe) $\left.{ }_{2} \mathbf{R u C l}_{\mathbf{2}}\right] \mathbf{( s )}$ : A solution of 1 ,4-Dioxane:DMF: $\mathrm{H}_{2} \mathrm{O}$ (3:2:1) was charged with $0.250 \mathrm{~g}$ ( 1 equiv.) of $\mathrm{RuCl}_{3} \bullet 3 \mathrm{H}_{2} \mathrm{O}$ and $0.100 \mathrm{~g}$ (2.0 equiv.) AnthbpyMe. To the solution mixture $0.5 \mathrm{~g}$ of $\mathrm{LiCl}$ was added and set to reflux for $4 \mathrm{~h}$. The complex was then collected and purified by the same procedure described above to give $0.130 \mathrm{~g}$ in $54 \%$ yield. The compound was characterized by HPLC-MS and absorption spectroscopy (Figures S3 and S4).

Synthesis of $\left[(\right.$ AnthbpyMe)(bpy)Ru(dpp) $]\left(\mathbf{P F}_{\mathbf{6}}\right)_{2}$, (2): (AnthbpyMe)(bpy) $\mathrm{RuCl}_{2(\mathrm{~s})}, 0.100 \mathrm{~g}$ (1.0 equiv.), was suspended in a $100 \mathrm{ml}$ round bottom flask containing $0.036 \mathrm{~g}$ (1.1 equiv.) of dpp and $30 \mathrm{ml}$ of $\left(1,4\right.$-dioxane, DMF, $\left.\mathrm{H}_{2} \mathrm{O} ; 3: 2: 1\right)$. The mixture was then refluxed for $6 \mathrm{~h}$ in the dark under $\operatorname{Ar}_{(\mathrm{g})}$ after which it was allowed to cool to room temperature and transferred into a saturated aqueous solution of $\mathrm{NH}_{4} \mathrm{PF}_{6 \text { (aq) }}$. The precipitate was collected by vacuum filtration and washed with $\mathrm{H}_{2} \mathrm{O}$ to remove any excess salt and then dried overnight. Purification was done by loading the crude product with a minimal amount of acetonitrile onto a 6 -inch alumina column (prepared with $100 \%$ ethyl acetate). The yellow/orange product band was then eluted with a 1:1 solvent mixture of acetonitrile:ethyl acetate containing $1 \% \mathrm{MeOH}$. The product was then loaded onto a 3-inch silica column, which was flushed with acetonitrile, chloroform, and $\mathrm{H}_{2} \mathrm{O}$. The yellow/orange product band was then eluted with $100 \mathrm{ml}$ solution of acetonitrile containing $10 \mathrm{ml}$ of concentrated $\mathrm{HCl}$ containing $1 \% \mathrm{MeOH}$. To the collected product was added $25 \mathrm{ml}$ of $\mathrm{NH}_{4} \mathrm{PF}_{6(\mathrm{aq})}$ solution and the volume of the acetonitrile was reduced to induce precipitation. The solid was then collected by vacuum filtration and allowed to dry overnight after washing with water. The solid was then dissolved with a minimum amount of DMF and precipitated with diethyl ether. The solid was collected and dried to give $0.090 \mathrm{~g}$ of desired product in 55\% yield. Spectral data: HPLC-MS (Figure S5), ESI-MS (Figure S6), ${ }^{1} \mathrm{H}$ NMR $\left(\mathrm{CD}_{3} \mathrm{CN}\right) ; \delta 2.59-261\left(3 \mathrm{H}, \mathrm{m} 4{ }^{\prime \prime}-\mathrm{CH} 3\right), 7.22-7.24(1 \mathrm{H}, \mathrm{d}), 7.31-741(2 \mathrm{H}, \mathrm{m}), 7.45-7.57$ $(4 \mathrm{H}, \mathrm{m}), 7.65-7.82(6 \mathrm{H}, \mathrm{m}), 7.87-7.97(4 \mathrm{H}, \mathrm{m}), 8.02-8.15(6 \mathrm{H}, \mathrm{m}), 8.21-8.25(1 \mathrm{H}, \mathrm{t}), 8.52-8.56$ $(5 \mathrm{H}, \mathrm{m}), 8.63-8.69(3 \mathrm{H}, \mathrm{dd}), 8.98-8.99(1 \mathrm{H}, \mathrm{d})$ 9.33-9.38(1H, m) (Figures S7, S8, and S9).

Synthesis of $\left[(\text { AnthbpyMe) })_{2} \mathbf{R u}\left(\mathbf{d p p}_{\mathbf{2}}\right)\right]\left(\mathbf{P F}_{\mathbf{6}}\right)_{2}$, (3): (AnthbpyMe)(bpy) $\mathrm{RuCl}_{2} 0.100 \mathrm{~g}$ (1 equiv.) was suspended in a $100 \mathrm{ml}$ round bottom flask containing $0.027 \mathrm{~g}$ (1.1 equiv.) of dpp and 30 $\mathrm{ml}$ of (1, 4-dioxane, DMF, $\mathrm{H}_{2} \mathrm{O} ; 3: 2: 1$ ). The mixture was refluxed for $6 \mathrm{~h}$, and then allowed to cool to room temperature. It was then transferred into a saturated solution of $\mathrm{NH}_{4(\text { aq) }}$. The precipitant was collected by vacuum filtration and washed with $\mathrm{H}_{2} \mathrm{O}$ to remove any remaining salt. The crude product was dried overnight. Purification was accomplished using the procedure described in section 2.1 .3 to give $0.095 \mathrm{~g}, 64 \%$ yield. Spectral data: HPLC-MS (Figure S10), ESI-MS (Figure S11), ${ }^{1} \mathrm{H}$ NMR $\left(\mathrm{CD}_{3} \mathrm{CN}\right): \delta 2.59-261(3 \mathrm{H}, \mathrm{m}), 7.22-7.24(1 \mathrm{H}$, $\mathrm{m}), 7.31-741(2 \mathrm{H}, \mathrm{m}), 7.45-7.57(2 \mathrm{H}, \mathrm{m}), 7.58-7.70(2 \mathrm{H}, \mathrm{m}), 7.71-7.75(1 \mathrm{H}, \mathrm{m}), 7.76-7.85$ $(1 \mathrm{H}, \mathrm{m}), 7.86-8.00(3 \mathrm{H}, \mathrm{m}), 8.01-8.10(2 \mathrm{H}, \mathrm{m}), 8.11-8.15(1 \mathrm{H}, \mathrm{m}), 8.51-8.54(2 \mathrm{H}, \mathrm{m}) 8.65-$ 8.68(2H, s) 8.98-9.04 (1H, dd) 9.35-9.45(1H, dd) (Figures S12, S13, and S14).

Electrochemistry: Cyclic voltammograms were obtained using a Bioanalytical Systems (BASI) Epsilon electrochemical analyzer using a three-electrode configuration and a singlecompartment cell. The supporting electrolyte was a $0.1 \mathrm{M}$ solution of tetrabutylammonium hexafluorophosphate $\left(\mathrm{Bu}_{4} \mathrm{NPF}_{6}\right)$ in $\mathrm{CH}_{3} \mathrm{CN}$; sample solutions were deoxygenated by purging with argon before each experiment. A platinum disk and platinum wire were used as the working electrode and the auxiliary electrode, respectively. The reference electrode was 
$\mathrm{Ag} / \mathrm{AgCl}$ in $3 \mathrm{M} \mathrm{NaCl}$, which was calibrated against the ferrocene/ferrocenium couple $\left(\mathrm{FeCp}^{2+/ 0}=0.46 \mathrm{~V}\right.$ vs $\left.\mathrm{Ag} / \mathrm{AgCl} 3 \mathrm{M} \mathrm{NaCl}\right)$ as an internal standard. ${ }^{36}$.

Electronic Absorption: An Agilent 8453 diode array spectrophotometer with $2 \mathrm{~nm}$ resolution was used to obtain the electronic absorption spectra. Extinction coefficients were determined at room temperature in a $1 \mathrm{~cm}$ quartz cell using solutions prepared gravimetrically in Burdick and Jackson UV-grade acetonitrile and are reported as an average of three measurements.

Excitation Spectra: Excitation spectra were recorded using a modified Photon Technology, Inc. QuantaMaster Model QM-200-45E. The system was modified to use a $150 \mathrm{~W}$ cooled xenon arc lamp excitation source with emission collected at a $90^{\circ}$ angle relative to the incident excitation by a thermoelectrically cooled Hamamatsu 1527 photomultiplier tube operating in photon counting mode. The emission intensities as a function of excitation wavelength were obtained at $660 \mathrm{~nm}$ with samples that were deoxygenated by bubbling through ultra-high purity argon for $10 \mathrm{~min}$.

Emission spectroscopy: The room temperature emission spectra were recorded in the same manner with the same instrumentation as used to obtain the excitation spectra. Air saturated samples were prepared, and the samples were then deoxygenated by bubbling through ultra high purity argon for 5-10 min. The quantum yields of emission $\left(\Phi_{\mathrm{em}}\right)$ were obtained by the ratio method using $\left[\mathrm{Ru}(\mathrm{bpy})_{3}\right]\left(\mathrm{PF}_{6}\right)_{2}$ with $\Phi_{\mathrm{em}}=0.062$ in deoxygenated conditions as the standard (SI equation 1$)^{8}{ }^{8}$

Emission Lifetimes: Emission lifetimes were obtained either by the time correlated single photon counting technique or pulse method. ${ }^{40,41,38}$. Time-correlated single photon counting measurements were obtained using a QuantaMaster QM-200-45E (PTI) equipped with a LED light source $(510 \mathrm{~nm}, \mathrm{FWHM} \sim 20 \mathrm{~nm}, \mathrm{PTI})$ and PM-20 TCSPC module SPC-130. Those emission lifetime decay profiles obtained by the pulse method were done so using a home built system in which the samples were excited with the output of Sirah Cobra Stretch dye laser equipped with Exalite 417 dye in dioxane tuned to $420 \mathrm{~nm}$ output. The dye laser was pumped by the third harmonic $(355 \mathrm{~nm})$ output of a Spectra Physics Indi-HG-10S Nd:YAG laser (10 $\mathrm{Hz}, 6$ ns pulse width). The signals were detected using an EOT ET-2030A amplified silicon detector equipped with a $420 \mathrm{~nm}$ notch filter to minimize any contribution of scattered excitation to the observed signal. The signals were digitized using a Tektronix TDS 754C 500 $\mathrm{MHz}(2 \mathrm{GS} / \mathrm{s})$ oscilloscope. Emission lifetime decay measurements were made at $90^{\circ}$ relative to the incident excitation pulse. Emission lifetime values were obtained using the DecayFit (www.fluortools.com) software package by a deconvolution/reconvolution process with the instrument response function (IRF). ${ }^{42}$ When necessary, additional scatter from the substrate/sample was accounted for in the deconvolution process.

High performance liquid chromatography-mass spectroscopy (HPLC-MS): $\mathrm{A}$ Luna $\mathrm{C}_{18}$ column (Phenomenox, Torance, CA), $150 \times 2.0 \mathrm{~mm}$ with $5 \mu \mathrm{m}$ particles was used in all separations. The mobile phase was acetonitrile and water (containing $1 \%$ formic acid, v/v). The gradient began at $95 \%$ water for $3 \mathrm{~min}$, then increased to $95 \%$ acetonitrile over the next 10 min and then held for $5 \mathrm{~min}$. The system was then ramped down to $95 \% / 5 \%\left(\mathrm{H}_{2} \mathrm{O} /\right.$ acetonitrile $)$ in $1 \mathrm{~min}$ and then equilibrated for an additional $5 \mathrm{~min}$ for a total analysis time of $22 \mathrm{~min}$. All 
samples were injected using a Thermo Survey Autosampler. Injection volume was $20 \mu \mathrm{L}$ at a concentration of $100 \mathrm{ng} / \mu \mathrm{L}$. The HPLC column effluent was pumped directly without any split into a Thermo Instrument TSQ triple quadrupole mass spectrometer (Thermo Finnigan, San Jose, CA) equipped with ESI source, which was used in positive ion MS mode.

Electrospray ionization-mass spectrometry: Mass spectrometry was recorded on an Agilent Technologies 6220 Accurate Mass TOF-LCMS with a dual ESI source in acetone or acetonitrile with $3.5 \mathrm{kV}$ electrospray voltage, $31 \mathrm{~V}$ cone voltage, $120^{\circ} \mathrm{C}$ source temperature, $\mathrm{N}_{2}$ nebulizing gas $(20 \mathrm{~L} / \mathrm{h})$, and scan range $250-700 \mathrm{~m} / \mathrm{z}$.

Nuclear magnetic resonance (NMR): ${ }^{1} \mathrm{H}$ NMR and ${ }^{1} \mathrm{H}-{ }^{1} \mathrm{H}$ COSY spectra were recorded on a JEOL $500 \mathrm{MHz}$ NMR spectrometer at $298 \mathrm{~K}$.

Cell culture: The F98 glioma cell line was obtained from ATCC and maintained in Dulbecco's Modified Eagle's Medium (DMEM, ATCC) supplemented with $10 \%$ fetal bovine serum (FBS, ATCC) and $1 \%$ penicillin/streptomycin at $37^{\circ} \mathrm{C}$ with $5 \% \mathrm{CO}_{2}$.

Photolysis: For photolysis treatments, 6 -well plates were seeded with $\sim 0.4 \times 10^{6}$ cells per well in $3.0 \mathrm{~mL}$ of DMEM and incubated at $37^{\circ} \mathrm{C}$ and $5 \% \mathrm{CO}_{2}$ for $24 \mathrm{~h}$. The medium was then evacuated from each well and replaced with $1.5 \mathrm{~mL}$ of the desired concentration of complex dissolved in DMSO ( $\leq 5 \% \mathrm{v} / \mathrm{v})$ and diluted in DMEM. A control was prepared by mixing the calculated amount of DMSO in the experimental samples with DMEM. The cells were then incubated at $37^{\circ} \mathrm{C}$ and $5 \% \mathrm{CO}_{2}$ for $15 \mathrm{~min}$. Each well was then evacuated and the cells were washed with PBS several times before incubating in DMEM without phenol red for $12 \mathrm{~h}$. Before the cells were photolyzed, each LED in the array was calibrated to $\sim 2.50 \mathrm{~mW}$ based on readings from a photodiode meter. ${ }^{43}$ The array was placed in an incubator at $37^{\circ} \mathrm{C}$ and $5 \%$ $\mathrm{CO}_{2}$. A thermocouple was placed inside the array to monitor the temperature around the cells. One at a time, each 6-well plate, except for the dark controls, was placed in the LED array for $1 \mathrm{~h}$.

Cell viability: Forty-eight hours after photolysis, each well was evacuated and replaced with a mixture of cold AlamarBlue $(10 \% \mathrm{v} / \mathrm{v})$ and DMEM to perform an indirect viability assay. ${ }^{44}$ The cells were incubated for $1.5 \mathrm{~h}$ with the AlamarBlue mixture. After incubation, $100 \mu \mathrm{L}$ from each mixed well was placed in 3 wells of a 96 well plate for each well to ensure more accurate readings. The 96 well plate was sealed with parafilm and kept in the dark at $4^{\circ} \mathrm{C}$ for 1 $2 \mathrm{~h}$ prior to measuring the absorption at 570 and $600 \mathrm{~nm}$ with a SpectraMax M2 spectrometer. Cell viability was calculated relative to the control for each of the samples (SI equation 2).

LED array: A LED array was designed to insure that only specifically characterized light was administered to the cell environment during treatment. The power source input was 120 volts AC with an output of 13.5 volts DC. A circuitry box was used to calibrate the output of each LED separately prior to the treatment. Two $5 \Omega$ resistors, wiring, a voltage controlling knob, and a LED were placed together for six LED channels with one light source per well in the treatment containers. The six LEDs were placed on a separate board from the circuitry to avoid excessive heating of the plates during treatment. The LED head board was placed on a mount 
designed to fit the dimensions of the well plates used in treatment and not let light either enter or escape to interrupt the photolysis.

\section{RESULTS AND DISCUSSION}

\section{Synthesis}

The metal-organic Ru(II) chromophores were synthesized and purified as detailed in the methods section (vide supra) and the supporting information (SI), with yields between 50$60 \%$. Characterization of 1,2 , and 3 was done by ${ }^{1} \mathrm{H}$ NMR, HPLC-MS, CV, steady-state emission and absorption spectroscopy, and ESI-MS.

\section{Electrochemistry}

Electrochemical analysis was used to identify relative ground state redox potentials of $\mathbf{1}, \mathbf{2}$, and 3. For comparison, both $\left[\mathrm{Ru}(\mathrm{bpy})_{3}\right]^{2+}$ and anthracene were also characterized and were found to display oxidation potentials at $\mathrm{E}_{1 / 2}$ of +1.25 and $\mathrm{E}_{\mathrm{p}}$ of $+1.24 \mathrm{~V}$ vs. $\mathrm{Ag} / \mathrm{AgCl}$, respectively. These correspond to the $\mathrm{Ru}^{\text {(III/II) }}$ reversible $1 \mathrm{e}^{-}$oxidation and irreversible anthracene oxidation, respectively. ${ }^{8,33}$ Complex 1 displays a characteristic $\mathrm{Ru}^{(\mathrm{III} / \mathrm{II})}$ reversible $1 \mathrm{e}^{-}$oxidation with an $\mathrm{E}_{1 / 2}$ of $1.45 \mathrm{~V}\left(\mathrm{Ag} / \mathrm{Ag}^{+}, 3 \mathrm{M} \mathrm{NaCl}\right)$ and a reversible reduction with an $\mathrm{E}_{1 / 2}$ of $-1.02 \mathrm{~V}$ $\left(\mathrm{Ag} / \mathrm{Ag}^{+}, 3 \mathrm{M} \mathrm{NaCl}\right)$ attributed to the $1 \mathrm{e}^{-} \mathrm{dpp}^{0 /-1}$ redox couple, Figure $2 .^{45}$

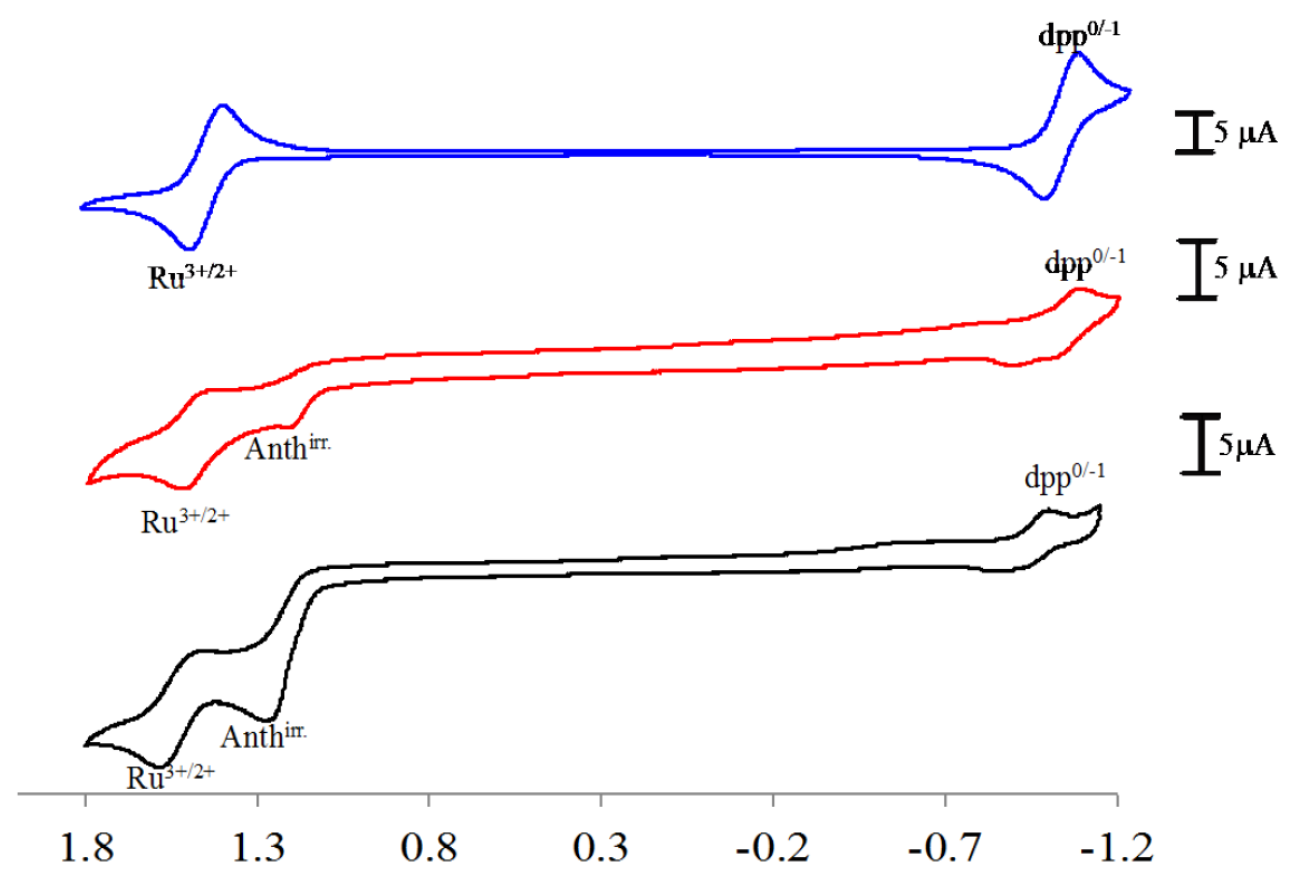

Potential (V) vs. $\mathrm{Ag} / \mathrm{Ag}^{+}, 3 \mathrm{M} \mathrm{NaCl}$

Figure 2. Cyclic voltammograms of $[($ bpy $) \mathrm{Ru}(\mathrm{dpp})]\left(\mathrm{PF}_{6}\right)_{2} \quad$ (blue, 1), $[($ AnthbpyMe $)($ bpy $) \mathrm{Ru}(\mathrm{dpp})]\left(\mathrm{PF}_{6}\right)_{2} \quad(\mathrm{red}, 2)$, and [(AnthbpyMe $\left.)_{2} \mathrm{Ru}(\mathrm{dpp})\right]\left(\mathrm{PF}_{6}\right)_{2}$ (black, $3)$, in $0.1 \mathrm{M} \mathrm{Bu}_{4} \mathrm{NPF}_{6} \mathrm{CH}_{3} \mathrm{CN}$, reported vs $\mathrm{Ag} / \mathrm{AgCl}(3 \mathrm{M} \mathrm{NaCl}$, scan rate $100 \mathrm{mV} / \mathrm{sec})$. 
Complexes 2 and 3 display reversible $1 \mathrm{e}^{-}$oxidation couples with an $\mathrm{E}_{1 / 2}$ of $1.52 \mathrm{~V}$ and $1.55 \mathrm{~V}\left(\mathrm{Ag} / \mathrm{Ag}^{+}, 3 \mathrm{M} \mathrm{NaCl}\right)$, respectively, which are assigned to the reversible oxidations of the $\mathrm{Ru}^{(\mathrm{III} / \mathrm{II})}$ centers. The irreversible oxidations at 1.24 and $1.28 \mathrm{~V}$ are attributed to the anthracene oxidation, which have been shown to undergo irreversible $2 \mathrm{e}^{-}$oxidation to form a di-cation product or nucleophilic attack by $\mathrm{CH}_{3} \mathrm{CN}^{46,47}$ The quasi-reversible $1 \mathrm{e}^{-}$reduction couple at $\mathrm{E}_{1 / 2}=-0.99 \mathrm{~V}\left(\mathrm{Ag} / \mathrm{Ag}^{+}, 3 \mathrm{M} \mathrm{NaCl}\right)$ is assigned to the $\mathrm{dpp} \mathrm{p}^{0 / 1}$ couple which is consistent with that of the parent complex (vide supra) (Figures S15 and S16). The observed anomalies between -0.8 and $-0.9 \mathrm{~V}\left(\mathrm{Ag} / \mathrm{Ag}^{+}, 3 \mathrm{M} \mathrm{NaCl}\right)$ are thought to be due to the irreversible reduction of the anthracene and/or amide linker units. ${ }^{48,46}$ Alternatively, these anomalies may be due to adsorption of the molecule onto the electrode. The small changes in the redox potential of the $\mathrm{Ru}^{(\mathrm{III} / \mathrm{II})}$ and $\mathrm{dpp}^{0 /-1}$ are also consistent with the spectroscopic results for the lowest lying MLCT transition.

\section{Photophysical properties}

Electronic absorption spectroscopy was used to determine the absorption properties of the reported complexes. Compound 1 displays a prominent electronic absorption band at $\sim 286 \mathrm{~nm}$ with a shoulder centered $\sim 325 \mathrm{~nm}$ attributed to overlapping bpy and dpp $\pi \rightarrow \pi^{*}$ transitions, and a broad absorption between $360 \mathrm{~nm}$ and $550 \mathrm{~nm}$ with a maxima $\sim 450 \mathrm{~nm}$ characteristic of population of a singlet metal-to-ligand charge transfer, ${ }^{1} \mathrm{MLCT}$, state from the ground state (Figure 3). ${ }^{49,50}$ These results are in relatively good agreement with previously published values of $\mathrm{Ru}(\mathrm{bpy})_{2}(\mathrm{dpp})$ in water. ${ }^{51,49}$ Assignment of the electronic configuration of the ${ }^{1} \mathrm{MLCT}$ state as being either $\operatorname{Ru}\left(\mathrm{d}_{\pi}{ }^{5}\right) \operatorname{bpy}\left(\pi^{*}\right)$ or $\operatorname{Ru}\left(\mathrm{d}_{\pi}^{5}\right) \operatorname{dpp}\left(\pi^{*}\right)$, where the promoted electron is localized on one of the bpy ligands or the dpp respectively, is difficult given the degree of overlap between the two transitions between $360 \mathrm{~nm}$ and $550 \mathrm{~nm}$. From the cyclic voltammetry, however, it is likely that the ${ }^{3}$ MLCT generated by very fast intersystem crossing resides on the lower energy dpp ligand based on the lower reduction potential of dpp relative to bpy. ${ }^{52,53}$

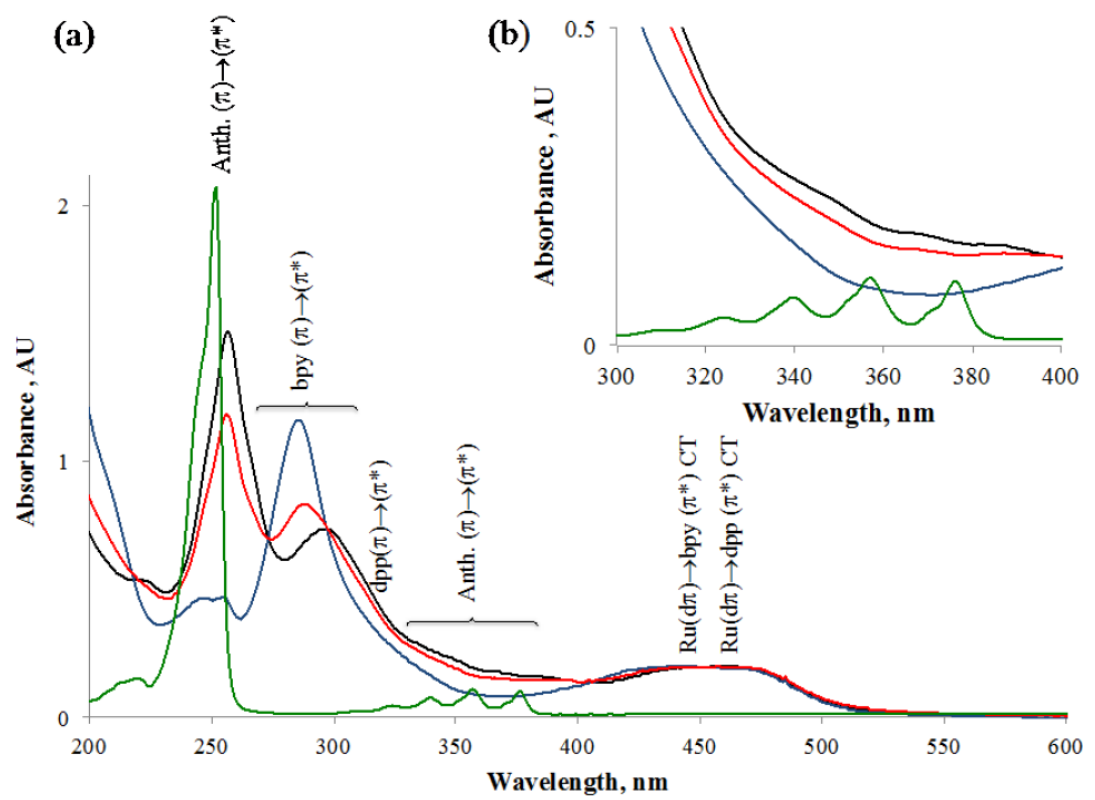

Figure 3. (a) Electronic absorption of anthracene (green), $\left[(\text { bpy })_{2} \mathrm{Ru}(\mathrm{dpp})\right]\left(\mathrm{PF}_{6}\right)_{2}$ (blue, 1), $\left[\left(\right.\right.$ AnthbpyMe)(bpy)Ru(dpp)] $\left(\mathrm{PF}_{6}\right)_{2}$ (red), and $\left[(\text { AnthbpyMe })_{2} \mathrm{Ru}(\mathrm{dpp})\right]\left(\mathrm{PF}_{6}\right)_{2}$ (black) in acetonitrile and (b) scale expansion of electronic absorption spectra. 
Complexes $\mathbf{2}$ and $\mathbf{3}$ exhibit strong absorption at $256 \mathrm{~nm}$ that is attributed to the short axis polarized anthracene $\pi \rightarrow \pi^{*}$ transition. ${ }^{54}$ The observed bathochromic shift of the bpy $\pi \rightarrow \pi^{*}$ transition for complex $\mathbf{2}$ and $\mathbf{3}$ from $\sim 286 \mathrm{~nm}$ to $\sim 300 \mathrm{~nm}$ is believed to arise from inductive effects due to functionalization of the bpy ligands at the 4 and 4 positions. ${ }^{55}$ In addition, the increased absorption observed between $\sim 325 \mathrm{~nm}$ to $\sim 425 \mathrm{~nm}$ is believed to arise from underlying transitions characteristic of anthracene absorption in the range of $350-400 \mathrm{~nm}$ corresponding to a $S_{0} \rightarrow S_{1}$ transition polarized along the long axis of the anthracene. ${ }^{54,56}$ The visible region displays absorption maxima centered at $459 \mathrm{~nm}$ for $2\left(\varepsilon=16,000 \mathrm{M}^{-1} \mathrm{~cm}^{-1}\right)$ and $461 \mathrm{~nm}$ for $3\left(\varepsilon=21,000 \mathrm{M}^{-1} \mathrm{~cm}^{-1}\right)$. These are attributed to ${ }^{1} \mathrm{MLCT}$ transitions corresponding to $\operatorname{Ru}\left(\mathrm{d}_{\pi}\right) \rightarrow \operatorname{bpy}\left(\pi^{*}\right), \operatorname{dpp}\left(\pi^{*}\right)$ with the dpp transition assigned the lowest lying MLCT transition (vide supra) ${ }^{57}$ The increase in the molar absorptivity as a function of anthracene subunits is a result of the interaction of the increase in ring current, which interacts significantly with the transition dipole moment of the ${ }^{1}$ MLCT transitions. ${ }^{58,4}$ Excitation spectra for the complexes were used to determine the contributions of the anthracene and $\mathrm{Ru}(\mathrm{II})$ core transitions to the emission intensity of the ${ }^{3}$ MLCT transition (Figure S17). The results corroborate interchromophoric interactions between the appended aromatic anthracene subunit, which give rise to phosphorescence from the ${ }^{3} \mathrm{MLCT}$. Parent complex $\mathbf{1}$ demonstrated a transition from $250-350 \mathrm{~nm}$ speculated to be from the bpy and dpp ligands. Complexes $\mathbf{2}$ and $\mathbf{3}$ present similar transitions, but with a bathochromatic shift and an additional transition from $350-400$ $\mathrm{nm}$ attributed to the anthracene.

Steady state emission shows that the excited state energies of the anthracene and $\mathrm{Ru}(\mathrm{II})$ core are not significantly perturbed by the covalent attachment of anthracene to the $\mathrm{Ru}$ complex. Excitation of complex $\mathbf{1}$ at $340 \mathrm{~nm}$ yields no emission within the near-UV region, while excitation at $\lambda_{\text {ex }}=450 \mathrm{~nm}$ gives rise to an emission band centered at $668 \mathrm{~nm}$, characteristic of the emissive ${ }^{3}$ MLCT state common to ruthenium polypyridyl and polyazine complexes. ${ }^{45}$ Conversely, excitation of $\mathbf{2}$ and $\mathbf{3}$ with $\lambda_{\mathrm{ex}}=340 \mathrm{~nm}$ gives rise to emissive high energy transitions with maxima located at $480 \mathrm{~nm}$ and a shoulder at $495 \mathrm{~nm}$ arising from anthracene singlet excited state relaxation (Figure 4).
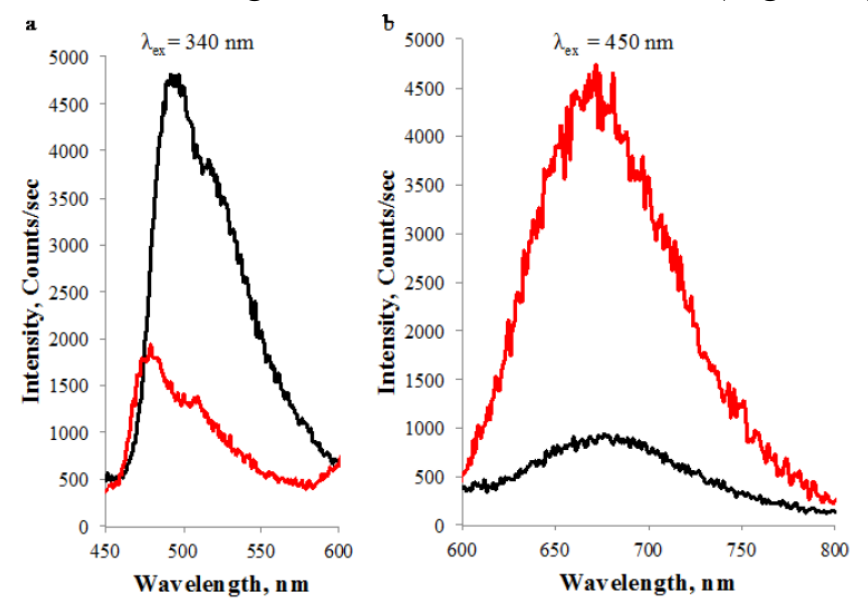

Figure 4. Steady state emission of $\left[(\right.$ AnthbpyMe) $($ bpy $) \mathrm{Ru}(\mathrm{dpp})]\left(\mathrm{PF}_{6}\right)_{2} \quad$ (red, 2), and $\left[(\text { AnthbpyMe })_{2} \mathrm{Ru}(\mathrm{dpp})\right]\left(\mathrm{PF}_{6}\right)_{2}$ (black, 3) in acetonitrile, excited at $340 \mathrm{~nm}$ (a) and $450 \mathrm{~nm}$ (b). Samples were absorbance matched at $450 \mathrm{~nm}$. 
The anthracene emission from complexes $\mathbf{2}$ and $\mathbf{3}$ displays decreased vibronic structure (compared to the vibronically resolved anthracene emission in solution) between $450-580 \mathrm{~nm}$ and is red-shifted relative to the anthracene emission $\left(\lambda_{\max }=394 \mathrm{~nm}\right)$. The red shift in the emission is common to 2-aminoanthracenes due to a twisted intramolecular charge transfer state (TICT). ${ }^{59,60}$ The TICT state has been proposed to lead to delocalized $\mathrm{e}^{-}$density into the $\left[(\mathrm{bpy})_{2} \mathrm{Ru}(\mathrm{ddp})\right]^{2+}$ system. $8,58,59$

Excitation of the anthracene moiety results in formation of an anthracene singlet excited state, which is known to undergo intersystem crossing to populate a triplet excited state. ${ }^{61}$ Both anthracene singlet and triplet states are depopulated via radiative and non-radiative decay pathways. The singlet emission lifetime observed for the parent 2-aminoanthracene was $\sim 10$ ns in $\mathrm{CH}_{3} \mathrm{CN}$. Upon covalent attachment to a bpy of the $\mathrm{Ru}$ complex the observed emission lifetime of the pendent anthracene was found to be $4.62 \mathrm{~ns}$ and $4.95 \mathrm{~ns}$ for complexes $\mathbf{2}$ and $\mathbf{3}$, respectively, upon excitation at $340 \mathrm{~nm}$, Figure 5.

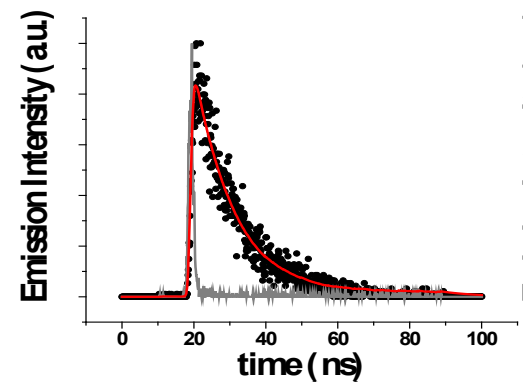

(a)

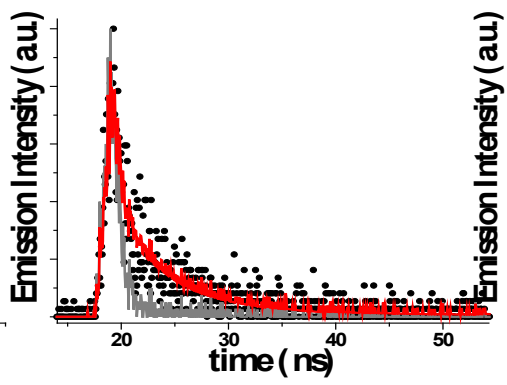

(b)

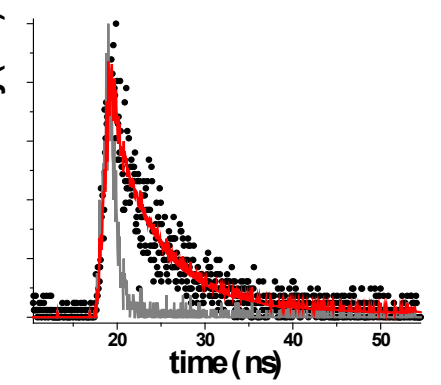

(c)

Figure 5. Emission lifetime decay (black circles) and corresponding deconvolution fit (red line) using an instrument response function (gray line) and a single exponential decay function for 2-aminoanthracene (a), $\quad\left[(\right.$ AnthbpyMe)(bpy)Ru(dpp) $]\left(\mathrm{PF}_{6}\right)_{2} \quad$ (b), $\quad$ and $\left[(\text { AnthbpyMe })_{2} \mathrm{Ru}(\mathrm{dpp})\right]\left(\mathrm{PF}_{6}\right)_{2}(\mathrm{c})$ in $\mathrm{CH}_{3} \mathrm{CN}$. Samples were excited at $\lambda_{\mathrm{ex}}=340 \mathrm{~nm}$.

The decreased emission lifetime of the anthracene singlet excited state is presumably due, at least in part, to intra- or inter- molecular energy transfer between the anthracene and the ruthenium core as evidenced by the presence of characteristic $\mathrm{Ru}$ emission upon excitation of the anthracene (vide supra). ${ }^{8}$ Similar results (i.e. quenching of the anthracene singlet excited state by a Ru-polypyridyl core) have been observed in other Ru(II)-polypyridyl-anthracenyl systems. ${ }^{14}$ The observed decay rate of the anthracene ligands of complexes $\mathbf{2}$ and $\mathbf{3}$ can be summarized as the sum of radiative $\left(\mathrm{k}_{\mathrm{r}}\right)$ and non-radiative $\left(\mathrm{k}_{\mathrm{nr}}\right)$ terms including a quenching rate constant $\left(\mathrm{k}_{\mathrm{q}}\right)$ (SI equation 3 ). From the fits of the anthracene emission lifetime decays, Figure 5, the quenching rates were found to be $1.16 \times 10^{8} \mathrm{~s}^{-1}$ and $1.02 \times 10^{8} \mathrm{~s}^{-1}$ for compounds 2 and 3 corresponding to quenching efficiencies $\left(\Phi_{\mathrm{q}}\right)$ of 0.538 and 0.505 , respectively, (SI equation 3). These values assume that the radiative and non-radiative rate constants of the anthracene emission in complexes $\mathbf{2}$ and $\mathbf{3}$ are the same as the anthracene moiety in the absence of the $\mathrm{Ru}(\mathrm{II})$-polypyridyl core.

The parent complex 1 has been reported as having a $\Phi_{\mathrm{em}}$ of 0.023 and found here to have a $\tau_{\mathrm{em}}$, of $540 \pm 1 \mathrm{~ns}$ upon generating the ${ }^{3} \mathrm{MLCT}$ state. ${ }^{45}$ Emission from the Ru(II) ${ }^{3} \mathrm{MLCT}$ state of 2 is centered at $661 \mathrm{~nm}\left(\lambda_{\mathrm{ex}}=450 \mathrm{~nm}\right)$ and was found to have a $\Phi_{\mathrm{em}}$ of 0.0059 , and an 
emission lifetime, $\tau_{\mathrm{em}}$, of $398 \pm 1 \mathrm{~ns}$ whereas 3 displayed an emission centered at $663 \mathrm{~nm}$, a $\Phi_{\mathrm{em}}$ of 0.0011 , and $\tau_{\mathrm{em}}$ of $414 \pm 1.0 \mathrm{~ns}$. It is evident from the observed $\Phi_{\mathrm{em}}$ and $\tau_{\mathrm{em}}$ for $\mathbf{1}, \mathbf{2}$, and $\mathbf{3}$ that covalent attachment of anthracene ligands to $\mathbf{1}$ is accompanied by quenching of the $\mathrm{Ru}$ (II) ${ }^{3} \mathrm{MLCT}$. It has been argued for similar compounds that functionalization of both the $\mathrm{Ru}(\mathrm{II})$ core and anthracene perturb the triplet energies of each in such a way that they become nearly isoenergetic. ${ }^{8}$

Förster theory of resonance energy transfer (FRET) was used to assess the contribution of excited state energy transfer to the quenching of the anthracene singlet state. ${ }^{62,63}$ The Förster overlap integral, $J$, Förster distance, $R_{o}$, refractive index, $\mathrm{n}$, donor lifetime, $\tau_{\mathrm{D}}$, and fluorescence quantum yield of the donor $\Phi_{\mathrm{D}}$, were determined to be $3.45 \times 10^{-14} \mathrm{~cm}^{6}, 37 \AA$, 1.344, $10 \mathrm{~ns}$, and 0.41, respectively, (Figure S18, SI equations $3-7$ ). From the former values a $\mathrm{k}_{\text {FRET }}$ of $1.7 \times 10^{11} \mathrm{~s}^{-1}$ was estimated assuming the distance between the Ru(bpy) $(\mathrm{dpp})$ and anthracene transition dipoles are approximately $11 \AA$ (obtained from cursory molecular modeling geometry optimizations using Arguslab, www.arguslab.com). The experimental FRET rate constants obtained are less characteristic of intramolecular FRET rates which are known to occur on vibrational timescales, i.e. $10^{10}-10^{12} \mathrm{~s}^{-1}$, and more characteristic of intermolecular (or diffusional) excited state electron transfer reactions. ${ }^{64,65}$

A Rhem-Weller analysis of the ground state redox energies and anthracene-excited state energy indicates that a mechanism in which the anthracene undergoes an excited state oxidative electron transfer to the dpp is thermodynamically downhill by at least $300 \mathrm{meV}$ (SI equation 8). ${ }^{66-68}$ These observations (e.g. ${ }^{3}$ MLCT emission upon anthracene excitation and the disparity between the experimental and predicted quenching rate constants via FRET) suggest that although excited state quenching of the anthracene singlet state is partially facilitated by FRET type mechanism, quenching by oxidative excited state electron transfer of the anthracene to the dpp ligand is possible according to Scheme 1.

Scheme 1. Mechanisms of Anthracene Quenching

$\mathrm{Ru}^{2+}\left(\mathrm{dpp}{ }^{-}\right)(\mathrm{bpy})\left(\mathrm{bpy}-\mathrm{Anth}^{-{ }^{+}}\right)$

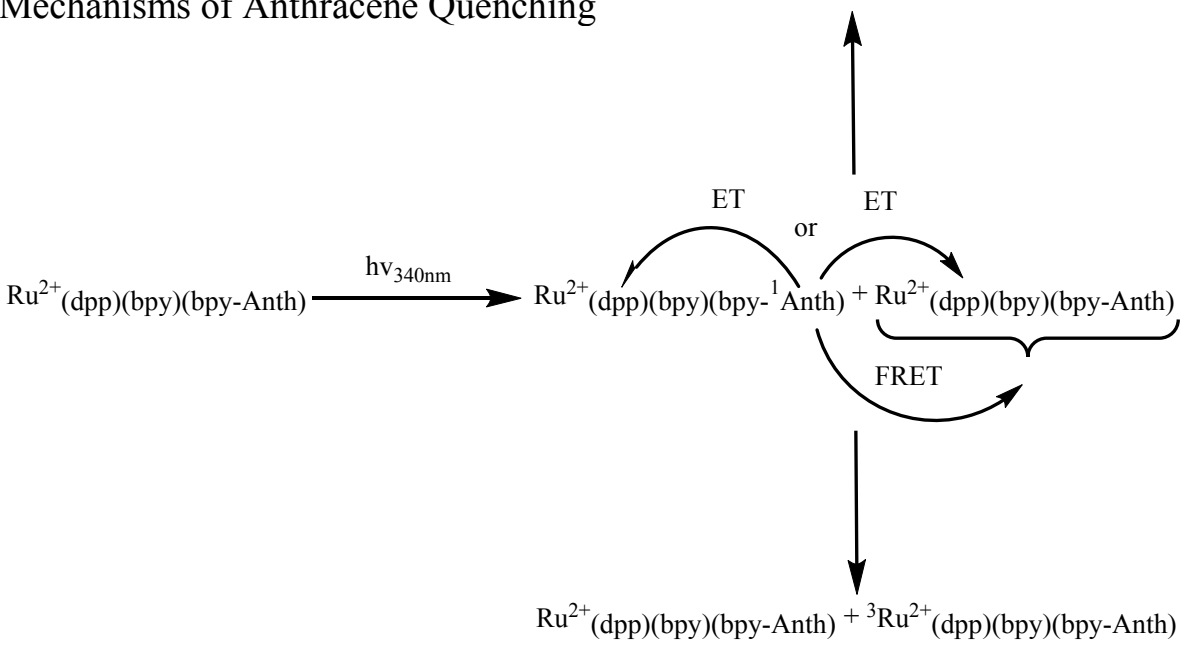

It should be noted that similar singlet energy transfer rates have been reported previously with $\mathrm{Ru}(\mathrm{II})(\mathrm{bpy})_{3}{ }^{69-71}$ 
Neither oxidative nor reductive excited state electron transfer are energetically favorable between the $\mathrm{Ru}(\mathrm{II}){ }^{3} \mathrm{MLCT}$ and anthracene ground state so that the most reasonable mechanism of ${ }^{3}$ MLCT quenching likely involves energy transfer between the Ru(II) ${ }^{3} \mathrm{MLCT}$ and the anthracene triplet excited state. The $\mathrm{Ru}(\mathrm{II})$ triplet quenching rate obtained by subtracting the observed decay rate of $\mathbf{1}$ from the observed decay rate of $\mathbf{2}$ and $\mathbf{3}$ (assuming that the rate of decay of $\mathbf{1}$ adequately approximates the rate of decay of $\mathbf{2}$ or $\mathbf{3}$ in the absence of the appended anthracene) were found to be approximately $6.61 \times 10^{5} \mathrm{~s}^{-1}$ for 2 and $5.64 \times 10^{5} \mathrm{~s}^{-}$ ${ }^{1}$ for 3. These values are consistent with those obtained in similar Ru(II)-anth systems (SI, equations $9-11$, Figure S19). ${ }^{8}$

Analysis of the Ru(II) emission lifetime decay of $\mathbf{2}$ and $\mathbf{3}$ was performed using a model for the Dexter exchange mechanism of energy transfer where the critical distance values, $R_{0}$, do not differ significantly between 2 and 3 and lie $\sim 8-10 \AA$ (SI, equation 6). ${ }^{72}$ Together with the calculated energy transfer efficiencies, the results are consistent with triplet energy transfer between the lowest ${ }^{3}$ MLCT and one of the anthracene ligands resulting in an anthracene in its triplet excited state.

In summary, depopulation of an excited anthracene subgroup occurs via competing pathways. Upon formation, the singlet excited state of anthracene may 1) undergo intersystem crossing to form a triplet excited state anthracene followed by decay to the ground state through predominately non-radiative pathways, 2) participate in inter-molecular Förster resonance energy transfer, or 3) participate in inter- or intra- electron transfer with the $\mathrm{Ru}(\mathrm{II})(\mathrm{bpy})_{2}$ (dpp). The quenching of the ${ }^{3} \mathrm{MLCT}$ also occurs by competing pathways: the ${ }^{3}$ MLCT state can undergo 1) inter- or intra- molecular resonance energy transfer by the Dexter exchange mechanism to populate ${ }^{3}$ anthracene, and/or 2) repopulate the ground state through radiative and non-radiative decay pathways inherent to the $\mathrm{Ru}(\mathrm{II})(\mathrm{bpy})_{2}(\mathrm{dpp})$.

\section{Photocytotoxicity and cytotoxicity toward MG cells}

To test the potential photocytotoxicity of the reported complexes for the treatment of brain cancers, F98 glioma cells were employed. This cell line is a widely-used rat brain tumor model with biological characteristics resembling those of human glioblastoma. ${ }^{70}$ Toxicity assays were conducted to test the effect of compounds 1, 2, and $\mathbf{3}$ against F98 glioma cells, with and without light activation. In brief, cells were treated with the complexes at a concentration of 75 $\mu \mathrm{M}$ for $1 \mathrm{~h}$, washed to remove excess complex remaining in the medium, and then incubated for $1 \mathrm{~h}$ in the dark or under illumination at $455 \mathrm{~nm}$ for which a custom-designed photoarray apparatus was employed. ${ }^{73,43}$ An AlamarBlue assay was used to quantify cell viability $48 \mathrm{~h}$ after treatment. In an effort to explore structure-function relationships in these compounds, anthracene (4), $\left[\mathrm{Ru}(\mathrm{bpy})_{3}\right]\left(\mathrm{PF}_{6}\right)_{2}(\mathbf{5})$, and $\left[(\mathrm{AnthbpyMe}) \mathrm{Ru}(\mathrm{bpy})_{2}\right]\left(\mathrm{PF}_{6}\right)_{2}(\mathbf{6})$ were also tested in parallel with the title complexes. ${ }^{8}$ 


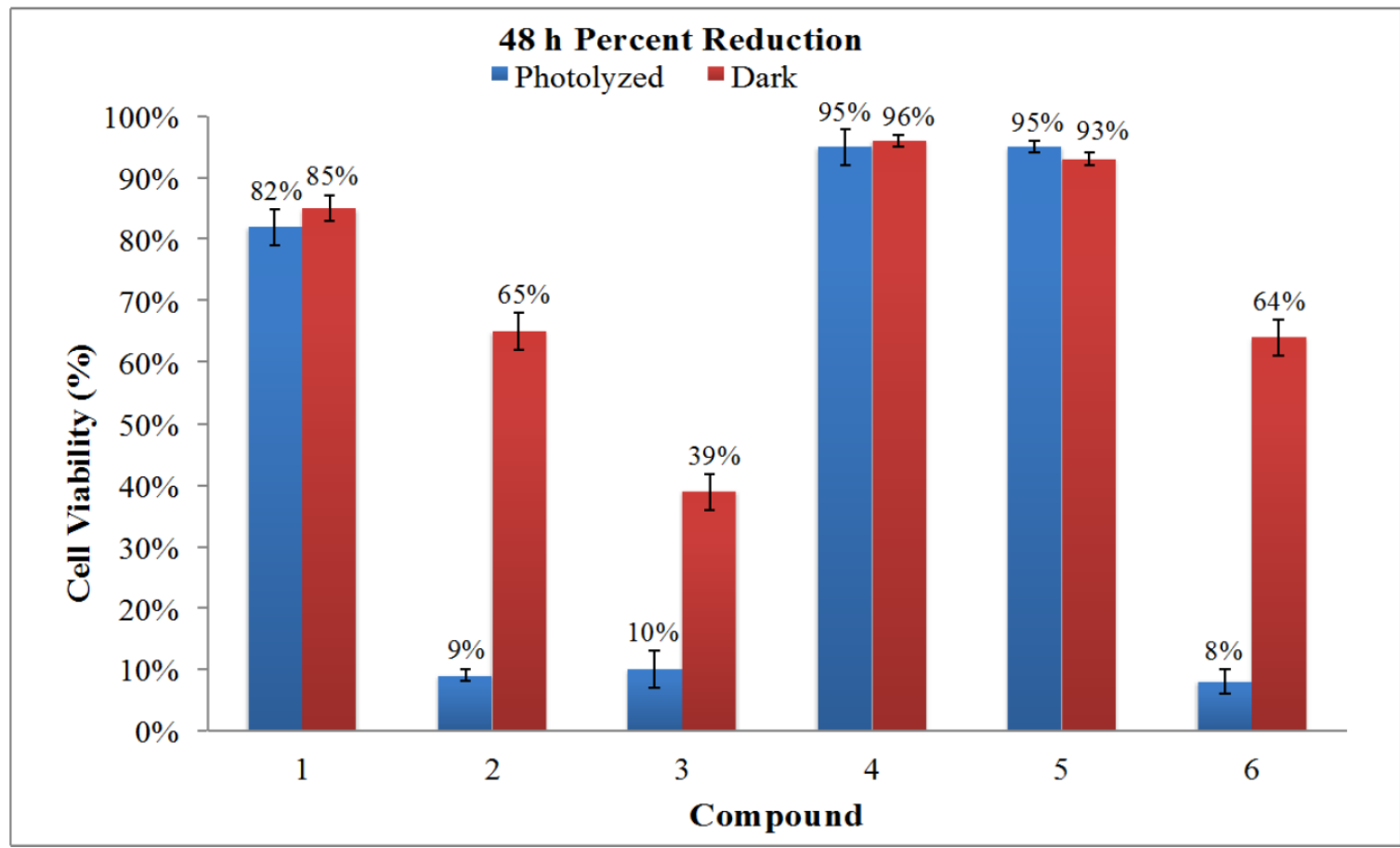

Figure 7. Effects of $\left[(\text { bpy })_{2} \mathrm{Ru}(\mathrm{dpp})\right]\left(\mathrm{PF}_{6}\right)_{2}$ (1), $\left[(\right.$ AnthbpyMe)(bpy) $\mathrm{Ru}(\mathrm{dpp})]\left(\mathrm{PF}_{6}\right)_{2}$ (2), $\left[(\text { AnthbpyMe })_{2} \mathrm{Ru}(\mathrm{dpp})\right](\mathrm{PF} 6)_{2} \quad(\mathbf{3}), \quad$ anthracene $\quad(\mathbf{4}), \quad\left[\mathrm{Ru}(\mathrm{bpy})_{3}\right]\left(\mathrm{PF}_{6}\right)_{2} \quad(\mathbf{5}), \quad$ and [(AnthbpyMe) $\left.\mathrm{Ru}(\mathrm{bpy})_{2}\right]\left(\mathrm{PF}_{6}\right)_{2}(\mathbf{6})$ against $\mathrm{F} 98 \mathrm{MG}$ cells $48 \mathrm{~h}$ after photolysis (viability counts were performed in triplicate; bars are standard error).

The cell viability at $48 \mathrm{~h}$ post-photolysis revealed that the parent molecules, anthracene (4) and $\left[\mathrm{Ru}(\mathrm{bpy})_{3}\right]^{2+}(\mathbf{5})$, exhibited relatively little cytotoxicity in either the absence or presence of light, while [(bpy $\left.)_{2} \mathrm{Ru}(\mathrm{dpp})\right]$ (1) was moderately cytotoxic under both dark and light conditions. In contrast, the complexes with appended anthracene moieties $(\mathbf{2}, \mathbf{3}$, and $\mathbf{6})$ displayed moderate toxicity in the dark, which was substantially enhanced by exposure to light. This photocytotoxicity is speculated to arise from the multiple deactivation pathways through energy and/or electron transfer processes, which can facilitate redox reactions and result in cell stress/death upon light activation.

\section{CONCLUSION}

Appending anthracene chromophores to the $\left[(\mathrm{bpy})_{2} \mathrm{Ru}(\mathrm{dpp})\right]^{2+}$ framework through amide linkers has resulted in structurally-diverse metal-organic $\mathrm{Ru}(\mathrm{II})$ complexes that exhibit unique photophysical properties and enhanced photodynamic potency against F98 glioma cells. Metal organic $\mathrm{Ru}(\mathrm{II})$ complexes, $[(\mathrm{AnthbpyMe})(\mathrm{bpy}) \mathrm{Ru}(\mathrm{dpp})]^{2}$ and $\left[(\mathrm{AnthbpyMe})_{2} \mathrm{Ru}(\mathrm{dpp})\right]^{2+}$, were prepared in moderate yields and characterized for their photophysical properties. Initial evaluation was also made of the phototoxicity of these compounds using the F98 rat glioma cell line. The complexes exhibit efficient light absorption throughout the UV region via ligand-based transition, while the visible region is dominated by MLCT transitions. The addition of the anthryl motif was shown to increase the efficiency with which the complexes absorb visible light, proposed to be caused by the interactions of the induced ring current with 
the induced dipole moment of the MLCT transitions. The excited-state properties (lifetimes and quantum yields) of the reported complexes were significantly perturbed relative to the parent complex $\left[(\mathrm{bpy}){ }_{2} \mathrm{Ru}(\mathrm{dpp})\right]^{2+}$ due to additional deactivation pathways provided by the appended anthracene(s). The excited state dynamics of the reported systems indicate that there is significant interchromophoric communication upon excitation of the anthracene and $\mathrm{Ru}(\mathrm{II})$ subunits. It is proposed that excitation of the anthracene subunit can be deactivated through direct electron transfer into the dpp bridging ligand or participate through a Dexter type energy transfer mechanism to populate the ${ }^{3}$ MLCT state. The ${ }^{3}$ MLCT excited state is also speculated to be depopulated through a Dexter type mechanism with efficient quenching between the triplet states of the anthracene. The dynamic excited state properties that are exhibited by these systems suggest that they have propensity for being novel agents for photodynamic therapy against highly invasive and aggressive forms of brain cancer that are intractable to conventional chemotherapeutic therapies. The complexes were shown to be moderately cytotoxic towards F98 rat glioma cells in the dark, an effect that was substantially enhanced upon illumination with visible light. This photocytotoxicity is hypothesized to arise from the unique excited state dynamics that are facilitated by appending an anthracene to the $\left[(\mathrm{bpy}){ }_{2} \mathrm{Ru}(\mathrm{dpp})\right]^{2+}$ system. Studies are currently underway to understand the photoreactivity of the proposed systems against cellular substrates such as DNA and protein and to examine the distribution of these complexes within exposed cells.

\section{ACKNOWLEDGMENTS}

The authors are grateful to the National Science Foundation (grant CHE-1301131) for financial support. Roberto Padilla received additional support from the National Institutes of Health IMSD Program (grant VT-IMSD-GM072767).

\section{SUPPLEMENTARY MATERIALS}

Supporting information can be found in the online version of article.

\section{REFERENCES}

1 Creutz, C.; Chou, M.; Netzel, T. L.; Okumura, M.; Sutin, N. (1980) Lifetimes, spectra, and quenching of the excited states of polypyridine complexes of iron(II), ruthenium(II), and osmium(II). J. Am. Chem. Soc. 102, 1309.

2 Damrauer, N. H.; McCusker, J. K. (1999) Ultrafast Dynamics in the Metal-to-Ligand Charge Transfer Excited-State Evolution of [Ru(4,4'-diphenyl-2,2'-bipyridine)3]2+. J. Phys. Chem. A 103, 8440.

3 Juris, A.; Balzani, V.; Barigelletti, F.; Campagna, S.; Belser, P.; von Zelewsky, A. (1988) $\mathrm{Ru}(\mathrm{II})$ polypyridine complexes: photophysics, photochemistry, eletrochemistry, and chemiluminescence. Coord. Chem. Rev. 84, 85.

4 McClenaghan, N. D.; Barigelletti, F.; Maubert, B.; Campagna, S. (2002) Towards ruthenium(ii) polypyridine complexes with prolonged and predetermined excited state lifetimes. Chem. Commun., 602. 
$5 \quad$ Meyer, T. J. In Pure Appl. Chem. 1986; Vol. 58, p 1193.

6 Albano, G.; Balzani, V.; Constable, E. C.; Maestri, M.; Smith, D. R. (1998) Photoinduced processes in $4^{\prime}-\left(9\right.$-anthryl)-2,2':6', $2^{\prime \prime}$-terpyridine, its protonated forms and $\mathrm{Zn}(\mathrm{II}), \mathrm{Ru}(\mathrm{II})$ and $\mathrm{Os}(\mathrm{II})$ complexes. Inorg. Chim. Acta 277, 225.

7 Castellano, F. N. (2015) Altering Molecular Photophysics by Merging Organic and Inorganic Chromophores. Acc. Chem. Res. 48, 828.

8 de Carvalho, I. M. M.; de Sousa Moreira, Í.; Gehlen, M. H. (2003) Synthesis, Characterization, and Photophysical Studies of New Bichromophoric Ruthenium(II) Complexes. Inorg. Chem. 42, 1525.

9 El-ghayoury, A.; Harriman, A.; Khatyr, A.; Ziessel, R. (2000) Intramolecular Triplet Energy Transfer in Metal Polypyridine Complexes Bearing Ethynylated Aromatic Groups. J. Phys. Chem. A 104, 1512.

10 Kercher, M.; König, B.; Zieg, H.; De Cola, L. (2002) Photoinduced Energy- and Electron-Transfer Processes within Dynamic Self-assembled Donor-Acceptor Arrays. J. Am. Chem. Soc. 124, 11541.

11 McClenaghan, N. D.; Leydet, Y.; Maubert, B.; Indelli, M. T.; Campagna, S. (2005) Excited-state equilibration: a process leading to long-lived metal-to-ligand charge transfer luminescence in supramolecular systems. Coord. Chem. Rev. 249, 1336.

12 Schoonover, J. R.; Dattelbaum, D. M.; Malko, A.; Klimov, V. I.; Meyer, T. J.; StyersBarnett, D. J.; Gannon, E. Z.; Granger, J. C.; Aldridge, W. S.; Papanikolas, J. M. (2005) Ultrafast Energy Transfer between the 3MLCT State of [RuII(dmb)2(bpyan)]2+ and the Covalently Appended Anthracene. J. Phys. Chem. A 109, 2472.

13 Serroni, S.; Campagna, S.; Pistone Nascone, R.; Hanan, G. S.; Davidson, G. J. E.; Lehn, J.-M. (1999) Controlling the Direction of Photoinduced Energy Transfer in Multicomponent Species. Chem. Eur. J. 5, 3523.

14 Wilson, G. J.; Launikonis, A.; Sasse, W. H.; Mau, A. W.-H. (1997) Excited-state processes in ruthenium(II) bipyridine complexes containing covalently bound arenes. J. Phys. Chem. A 101, 4860.

15 Fleisher, M. B.; Waterman, K. C.; Turro, N. J.; Barton, J. K. (1986) Light-induced cleavage of DNA by metal complexes [1]. Inorg. Chem. 25, 3549.

16 Lincoln, R.; Kohler, L.; Monro, S.; Yin, H.; Stephenson, M.; Zong, R.; Chouai, A.; Dorsey, C.; Hennigar, R.; Thummel, R. P.; McFarland, S. A. (2013) Exploitation of Long-Lived 3IL Excited States for Metal-Organic Photodynamic Therapy: Verification in a Metastatic Melanoma Model. J. Am. Chem. Soc. 135, 17161.

17 Liu, J.; Chen, Y.; Li, G.; Zhang, P.; Jin, C.; Zeng, L.; Ji, L.; Chao, H. (2015) Ruthenium(II) polypyridyl complexes as mitochondria-targeted two-photon photodynamic anticancer agents. Biomaterials 56, 140.

18 Mari, C.; Pierroz, V.; Ferrari, S.; Gasser, G. (2015) Combination of Ru(ii) complexes and light: new frontiers in cancer therapy. Chemical Science 6, 2660.

19 Mariappan, M.; Maiya, B. G. (2005) Effects of Anthracene and Pyrene Units on the Interactions of Novel Polypyridylruthenium(II) Mixed-Ligand Complexes with DNA. Eur. J. Inorg. Chem. 2005, 2164.

20 Monro, S.; Scott, J.; Chouai, A.; Lincoln, R.; Zong, R.; Thummel, R. P.; McFarland, S. A. (2010) Photobiological Activity of Ru(II) Dyads Based on (Pyren-1-yl)ethynyl Derivatives of 1,10-Phenanthroline. Inorg. Chem. 49, 2889. 
21 Shi, G.; Monro, S.; Hennigar, R.; Colpitts, J.; Fong, J.; Kasimova, K.; Yin, H.; DeCoste, R.; Spencer, C.; Chamberlain, L.; Mandel, A.; Lilge, L.; McFarland, S. A. (2015) $\mathrm{Ru}(\mathrm{II})$ dyads derived from $\alpha$-oligothiophenes: A new class of potent and versatile photosensitizers for PDT. Coord. Chem. Rev. 282-283, 127.

22 Castro, M. G.; Cowen, R.; Williamson, I. K.; David, A.; Jimenez-Dalmaroni, M. J.; Yuan, X.; Bigliari, A.; Williams, J. C.; Hu, J.; Lowenstein, P. R. (2003) Current and future strategies for the treatment of malignant brain tumors. Pharmacol. Ther. 98, 71.

23 Maher, E. A.; Furnari, F. B.; Bachoo, R. M.; Rowitch, D. H.; Louis, D. N.; Cavenee, W. K.; DePinho, R. A. (2001) Malignant glioma: genetics and biology of a grave matter. Genes Dev. 15, 1311.

24 Reardon, D. A.; Rich, J. N.; Friedman, H. S.; Bigner, D. D. (2006) Recent Advances in the Treatment of Malignant Astrocytoma. J. Clin. Oncol. 24, 1253.

25 Mongelli, M. T.; Heinecke, J.; Mayfield, S.; Okyere, B.; Winkel, B. S. J.; Brewer, K. J. (2006) Variation of DNA photocleavage efficiency for [(TL)2Ru(dpp)]Cl2 complexes where $\mathrm{TL}=2,2^{\prime}$-bipyridine, 1,10-phenanthroline, or 4,7-diphenyl-1,10-phenanthroline. J. Inorg. Biochem. 100, 1983.

26 Gomer, C. J. (1991) Preclinical examination of first and second generation photosensitizers used in photodynamic therapy. Photochem. Photobiol. 54, 1093.

27 Josefsen, L. B.; Boyle, R. W. (2008) Photodynamic therapy: novel third-generation photosensitizers one step closer? Br. J. Pharmacol. 154, 1.

28 Kumar, C. V.; Punzalan, E. H. A.; Tan, W. B. (2000) Adenine-Thymine Base Pair Recognition by an Anthryl Probe from the DNA Minor Groove. Tetrahedron 56, 7027.

29 Lewis, F. D.; Liu, W. (1999) Luminescence of N-Arylbenzamides in Low-Temperature Glasses. J. Phys. Chem. A 103, 9678.

30 Castano, A. P.; Demidova, T. N.; Hamblin, M. R. (2004) Mechanisms in photodynamic therapy: part one-photosensitizers, photochemistry and cellular localization. Photodiagnosis Photodyn. Ther. 1, 279.

31 Weinheimer, C.; Choi, Y.; Caldwell, T.; Gresham, P.; Olmsted Iii, J. (1994) Effect of a steric spacer on chromophoric interactions of ruthenium complexes containing covalently bound anthracene. J. Photochem. Photobiol. A 78, 119.

32 Padilla, R.; Corrales, J. A. R.; Donohoe, L. E.; Winkel, B. S. J.; Brewer, K. J. (2015) Uncovering a New Class of Ru(II) Polyazine Light Harvesting PDT Agent: A New Molecular Frontier Manuscript in preperation.

33 Zigler, D. F.; Elvington, M. C.; Heinecke, J.; Brewer, K. J. (2006) Luminescently Tagged 2,2'-Bipyridine Complex of FeII: Synthesis and Photophysical Studies of 4[N-(2-Anthryl)carbamoyl]-4'-methyl-2,2‘-bipyridine. Inorg. Chem. 45, 6565.

34 Bennett, M. A.; Huang, T. N.; Matheson, T. W.; Smith, A. K.; Ittel, S.; Nickerson, W. In Inorg. Synth.; John Wiley \& Sons, Inc.: 2007, p 74.

35 Zelonka, R. A.; Baird, M. C. (1972) Benzene Complexes of Ruthenium(II). Can. J. Chem. 50, 3063.

36 Bard, A. J.; Faulkner, L. R. Electrochemical methods : fundamentals and applications; 2nd ed.; Wiley: New York, 2001.

37 Kawanishi, Y.; Kitamura, N.; Tazuke, S. (1989) Dependence of spectroscopic, electrochemical, and excited-state properties of tris chelate ruthenium(II) complexes on ligand structure. Inorg. Chem. 28, 2968. 
Valeur, B.; Berberan-Santos, M. N. Molecular fluorescence : principles and applications; Second edition. ed.; Wiley-VCH Verlag GmbH \& Co. KGaA: Weinheim, Germany, 2013.

39 Wallace, A. W.; Murphy, R. J., W.; Petersen, J. D. (1989) Electrochemical and photophysical properties of mono- and bimetallic ruthenium(II) complexes. Inorg. Chim. Acta 166, 47.

40 Demas, J. N. Excited state lifetime measurements; Academic Press: New York, 1983.

41 O'Connor, D. V.; Phillips, D. Time-correlated single photon counting; Academic Press: London, 1984.

42 Baba, A. I.; Shaw, J. R.; Simon, J. A.; Thummel, R. P.; Schmehl, R. H. (1998) The photophysical behavior of d6 complexes having nearly isoenergetic MLCT and ligand localized excited states. Coord. Chem. Rev. 171, 43.

43 Zhu, J.; Prussin, R.; Dominijanni, A.; Brewer, K. J.; Robertson, J. L. (2015) Exploring Cellular Activity of a Polyazine Bridged Ru(II)-Pt(II) Supramolecule in Rat Malignant Glioma F98. Manuscript in progress.

44 O'Brien, J.; Wilson, I.; Orton, T.; Pognan, F. (2000) Investigation of the Alamar Blue (resazurin) fluorescent dye for the assessment of mammalian cell cytotoxicity. Eur. $\mathrm{J}$. Biochem. 267, 5421.

45 Mongelli, M. T.; Brewer, K. J. (2006) Synthesis and study of the light absorbing, redox and photophysical properties of $\mathrm{Ru}(\mathrm{II})$ and Os(II) complexes of 4,7-diphenyl-1,10phenanthroline containing the polyazine bridging ligand 2,3-bis(2-pyridyl)pyrazine. Inorg. Chem. Commun. 9, 877.

46 Weinberg, N. L.; Weinberg, H. R. (1968) Electrochemical oxidation of organic compounds. Chem. Rev. 68, 449.

47 Wilson, G. J.; Launikonis, A.; Sasse, W. H. F.; Mau, A. W. H. (1997) Excited-State Processes in Ruthenium(II) Bipyridine Complexes Containing Covalently Bound Arenes. J. Phys. Chem. A 101, 4860.

48 Simon, J. A.; Curry, S. L.; Schmehl, R. H.; Schatz, T. R.; Piotrowiak, P.; Jin, X.; Thummel, R. P. (1997) Intramolecular Electronic Energy Transfer in Ruthenium(II) Diimine Donor/Pyrene Acceptor Complexes Linked by a Single C-C Bond. J. Am. Chem. Soc. 119, 11012.

49 Brewer, K. J.; Murphy Jr, W. R.; Spurlin, S. R.; Petersen, J. D. (1986) The next generation of (polyazine) ruthenium (II) complexes. Inorg. Chem. 25, 882.

50 Juris, A.; Balzani, V.; Barigelletti, F.; Campagna, S.; Belser, P. 1.; Von Zelewsky, A. (1988) Ru (II) polypyridine complexes: photophysics, photochemistry, eletrochemistry, and chemiluminescence. Coord. Chem. Rev. 84, 85.

51 Braunstein, C. H.; Baker, A. D.; Strekas, T. C.; Gafney, H. D. (1984) Spectroscopic and electrochemical properties of the dimer tetrakis (2, 2'-bipyridine)(. mu.-2, 3-bis (2pyridyl) pyrazine) diruthenium (II) and its monomeric analog. Inorg. Chem. 23, 857.

52 Crosby, G.; Demas, J. (1971) Quantum efficiencies on transition metal complexes. II. Charge-transfer luminescence. J. Am. Chem. Soc. 93, 2841.

53 Lumpkin, R. S.; Kober, E. M.; Worl, L. A.; Murtaza, Z.; Meyer, T. J. (1990) Metal-toligand charge-transfer (MLCT) photochemistry: experimental evidence for the participation of a higher lying MLCT state in polypyridyl complexes of ruthenium(II) and osmium(II). J. Phys. Chem. 94, 239. 

Hydrocarbons. J. Chem. Phys. 17, 470.

55 Mecklenburg, S. L.; Peek, B. M.; Schoonover, J. R.; McCafferty, D. G.; Wall, C. G.; Erickson, B. W.; Meyer, T. J. (1993) Photoinduced electron transfer in amino acid assemblies. J. Am. Chem. Soc. 115, 5479.

56 Mecklenburg, S. L.; McCafferty, D. G.; Schoonover, J. R.; Peek, B. M.; Erickson, B. W.; Meyer, T. J. (1994) Spectroscopic Study of Electron Transfer in a Trifunctional Lysine with Anthraquinone as the Electron Acceptor. Inorg. Chem. 33, 2974.

57 Lumpkin, R. S.; Kober, E. M.; Worl, L. A.; Murtaza, Z.; Meyer, T. J. (1990) Metal-toLigand Charge-Transfer (Mlct) Photochemistry - Experimental-Evidence for the Participation of a Higher Lying Mlct State in Polypyridyl Complexes of Ruthenium(Ii) and Osmium(Ii). J. Phys. Chem. 94, 239.

58 Dey, J.; Warner, I. M. (1997) Dual Fluorescence of 9-(N,NDimethylamino)anthracene: Effect of Solvent Polarity and Viscosity. J. Phys. Chem. A 101, 4872.

59 Rettig, W. In Electron Transfer I; Mattay, J., Ed.; Springer Berlin Heidelberg: 1994; Vol. 169, p 253.

60 Suresh, M.; Kar, P.; Das, A. (2010) Intramolecular Charge Transfer aromatic amines and their application towards molecular logic gate. Inorg. Chim. Acta 363, 2881.

61 Turro, N. J. Modern molecular photochemistry; Benjamin/Cummings Pub. Co.: Menlo Park, Calif., 1978.

62 Forster, T. (1959) 10th Spiers Memorial Lecture - Transfer Mechanisms of Electronic Excitation. Discussions of the Faraday Society, 7.

63 Forster, T. (1948) *Zwischenmolekulare Energiewanderung Und Fluoreszenz. Annalen Der Physik 2, 55.

64 Bock, C. R.; Meyer, T. J.; Whitten, D. G. (1974) Electron transfer quenching of the luminescent excited state of tris(2,2'-bipyridine)ruthenium(II). Flash photolysis relaxation technique for measuring the rates of very rapid electron transfer reactions. J. Am. Chem. Soc. 96, 4710.

65 Ward, M. D. (1997) Photo-induced electron and energy transfer in non-covalently bonded supramolecular assemblies. Chem. Soc. Rev. 26, 365.

66 Knibbe, H.; Rehm, D.; Weller, A. (1967) Formation of Electron Donor-Acceptor Complexes in Stimulated State. Ber. Bunsen-Ges. Phys. Chem 71, 916.

67 Knibbe, H.; Rehm, D.; Weller, A. (1968) Intermediates and Kinetics of Fluorescence Quenching by Electron Transfer. Ber. Bunsen-Ges. Phys. Chem 72, 257.

68 Knibbe, H.; Rehm, D.; Weller, A. (1969) Thermodynamics of Excited Electron DonorAcceptor Complex Formation. Ber. Bunsen-Ges. Phys. Chem 73, 839.

69 Mandal, K.; Demas, J. N. (1981) Surfactant-enhanced singlet energy transfer from the charge-transfer excited state of tris(2,2-bipyridine) ruthenium(II). Chem. Phys. Lett. $84,410$.

70 Mandal, K.; Pearson, T. D. L.; Demas, J. N. (1980) Singlet energy transfer from the charge transfer excited state of tris (2,2' - bipyridine) ruthenium (II). J. Chem. Phys. 73, 2507.

71 Mandal, K.; Pearson, T. D. L.; Krug, W. P.; Demas, J. N. (1983) Singlet energy transfer from the charge-transfer excited state of tris(2,2'-bipyridine)ruthenium(II) to laser dyes. J. Am. Chem. Soc. 105, 701. 
72 Inokuti, M.; Hirayama, F. (1965) Influence of energy transfer by the exchange mechanism on donor luminescence. J. Chem. Phys. 43, 1978.

73 Zhu, J.; Prussin, R.; Dominijanni, A.; Brewer, K. J.; Robertson, J. L. (2015) Exploring Cellular Activity of a Polyazine Bridged Ru(II)-Pt(II) Supramolecule in Rat Malignant Glioma F98. Manuscript in preperation. A breif summary is found in SI. 